5. This standard error of estimate was found to be of such a magnitude that it can cause a standard error of about 3.5 N.P.U. units if only four albino rats are being used in Bender-Miller tests.

We are grateful to Mr R. S. Hall of the N.I.P.R. (C.S.I.R.), and Dr D. J. Stoker of the University of Pretoria for their assistance in the statistical analysis. The technical assistance of Anna Bester, D. B. du Bruyn and S. A. Fellingham is gratefully acknowledged.

This paper is published with the permission of the South African Council for Scientific and Industrial Research.

\title{
REFERENCES
}

Bender, A. E. \& Miller, D. S. (r953a). Biochem. F. 53, vii.

Bender, A. E. \& Miller, D. S. (1953b). Biochem. F. 53, vii.

Forbes, R. M. \& Yohe, M. (1955). F. Nutr. 55, 493.

Hemelrijk, J. (1952). Rapport S73 (M 77 a). Amsterdam: Statistisch Afdeling, Matematisch Centrum.

Mann, H. B. \& Whitney, D. (1947). Ann. math. Statist. 18, 50.

Michell, H. H. (1923-4). F. biol. Chem. 58, 873 .

Perrin, C. H. (1953). Analyt. Chem. 25, 968.

Terpstra, T. J. (1952). Indag. math. I4, 327.

Terpstra, T. J. (1953). Indag. math, r5, 433.

Thomas, K. (r9o9). Arch. Anat. Physiol., Lpz. (Physiol. Abt.), p. 219.

Wabeke, D. \& van Eeden, C. (1955). Rapport S I67 (M65). Amsterdam: Statistisch Afdeling, Matematisch Centrum.

Wallis, W. A. (1942). Econometrica, ro, 229.

Wilcoxon, F. (1945). Biomet. Bull. 1, 80.

\section{Thiamine in the contents of the alimentary tract of sheep}

\author{
By A. T. PHILLIPSON AND R. S. REID \\ Rowett Research Institute, Bucksburn, Aberdeenshire
}

(Received 9 fuly $\mathrm{1956)}$

Interest in the thiamine content of the rumen has been aroused again by the discovery that bracken contains a factor splitting the thiamine molecule into its component pyrimidine and thiazol fractions (Weswig, Freed \& Haag, 1946; Carpenter, Phillipson \& Thomson, I950; Evans, Evans \& Roberts, I95I). Typical signs of vitamin $\mathrm{B}_{1}$ deficiency were obtained in rats and in the horse by the feeding of considerable amounts of bracken and were abolished by injections of thiamine. The thiamine content of the rumen digesta in bracken-fed cattle was found to be very small indeed (Phillipson \& Reid, I954), but the syndrome known as bracken poisoning in cattle is not at all like a thiamine deficiency, nor can it be prevented or cured by massive injections of thiamine (Carpenter et al. 1950; Evans et al. 1951; Naftalin \& Cushnie, 1954). From this evidence it might be inferred that the requirements for thiamine in the adult ruminant are small. However, nearly all the existing work on thiamine has been confined to the rumen and little is known about the distribution of thiamine in 
the rumen contents or of the influence of the food on the concentrations present in the whole alimentary tract, so the work described in this paper was undertaken before any renewed attempt was made to study the results of bracken feeding on the available thiamine present in the alimentary tract.

\section{EXPERIMENTAL \\ Animals}

Sixteen sheep were used of either the North Country Cheviot or the Scottish Blackface breed. They were kept in groups of three or four and were maintained for at least 2 months on each ration tested.

\section{Food}

The rations fed during the course of these investigations were:

(A) Chopped hay at the rate of $1360 \mathrm{~g} /$ head/day.

(B) Chopped hay, $900 \mathrm{~g}$, with $225 \mathrm{~g}$ of a supplement consisting of 2 parts linseed meal and I part crushed oats. This supplement is referred to hereafter as supplement no. 6.

(C) Chopped hay, $675 \mathrm{~g}$, with $225 \mathrm{~g}$ of a supplement consisting of ground maize 4 parts, crushed oats I part, wheat bran I part, linseed meal $\frac{1}{2}$ part and fish meal $\frac{1}{2}$ part. This supplement is referred to hereafter as supplement no. I.

(D) Chopped hay, $150 \mathrm{~g}$, with $1000 \mathrm{~g}$ of a supplement consisting of 900 parts flaked maize, 95 parts maize-gluten meal, 2 parts steamed bone-flour and salt.

(E) Chopped hay, $454 \mathrm{~g}$, and chopped fodder-beet $3405 \mathrm{~g}$.

(F) Chopped hay, 681 g, and extracted decorticated groundnut meal $340 \mathrm{~g}$.

(G) Grass cubes fed to a limit of $1360 \mathrm{~g}$ daily.

(H) Free grazing at pasture.

Rations A, D, E, F and G were given in two meals daily; half the ration was fed at 7.30 a.m. and the other half at 4.00 p.m., except that with ration $D$ the flaked-maize supplement was fed at $7.30 \mathrm{a} . \mathrm{m}$. and the hay at 4.00 p.m. Rations $\mathrm{B}$ and $\mathrm{C}$ were given in three meals; half the hay was given at $7.30 \mathrm{a} . \mathrm{m}$. , half at $4.00 \mathrm{p} . \mathrm{m}$. and the concentrate at II.00 a.m.

\section{Collection of samples}

All sheep were fitted with an ebonite rumen cannula by the standard technique. Two animals, both Scottish Blackfaces, were used for the intestinal studies. Perspex cannulas were inserted into the caudal part of the duodenum beyond the entrance of the common bile and pancreatic ducts, by means of the approach described by Phillipson \& Mitchell (1952). At a subsequent operation a cannula was inserted into the caecum about $3-4$ in. from the opening of the ileum towards the apex, and a Perspex cannula of the same design as that used for the duodenum was inserted into the ileum about 12-18 in. from the ileo-caecal junction. The sheep recovered uneventfully from these operations and their appetite was normal. Samples were taken normally between 9.00 and 9.30 a.m. except when large samples were needed for fractionation. These were taken earlier. 
Rumen contents were withdrawn by suction through a wide ebonite tube of $\frac{3}{4}$ in. internal diameter directly into a flask containing $2.5-3 \mathrm{ml}$. of $60 \%(\mathrm{v} / \mathrm{v})$ conc. sulphuric acid. On continually shaking the flask the contents became evenly acidified so that bacterial action was arrested. A small Perspex device was inserted down the shaft of the duodenal and ileal cannulas. It is illustrated in P1. I. The shaft was semicircular, so that on blocking the intestinal lumen with the tip the digesta flowed up the shaft of the cannula into the collecting flask. This device did not guarantee that all the digesta being propelled along the intestine flowed from the cannula but the flow was rapid enough to suggest that most passed from the cannula into the collecting bottle.

The caecal cannula had a shaft with an internal bore of $16 \mathrm{~mm}$ and was similar in design to the intestinal cannula. The caecal contents were too sticky and thick to flow from the cannula, and a Perspex scoop, illustrated in P1. 1, was made by means of which it was easy to lift caecal contents through the shaft of the cannula. Since $300 \mathrm{ml}$. were collected at a time the concentration error due to the $2 \cdot 5-3 \mathrm{ml}$. acid in the container was negligible and was neglected in all calculations.

When the sheep were at grass, they were fitted with a canvas body covering, with a flap on the left side that could be lifted to expose the rumen cannula. Daily attention was essential when the sheep were at pasture, in order to keep the area around the cannula clean.

\section{Fractionation of rumen contents}

The rumen contents were partitioned into various fractions representative of plant residues, rumen micro-organisms and water. Large samples were drawn for this purpose, and thiamine was estimated in the parent sample and in the fractions derived from it. The procedure of fractionation was as follows:

Large plant particles were separated by filtering through four layers of surgical gauze. 'The plant material on the gauze was washed several times with $0 \cdot 1 \mathrm{~N}$-sulphuric acid, transferred to a dish, dried and weighed. Thiamine estimations were made on samples of the dried material and the total thiamine present in the plant residues on the gauze was calculated. The filtrate, referred to as 'muslin' filtrate, was sampled and its thiamine content was estimated. Another portion of the original sample was treated in the same way, but the 'muslin' filtrate was passed through a Sharples centrifuge. The deposit separated from the liquid, referred to as 'sludge', was weighed, the volume of the supernatant liquid being noted. The sludge consisted of fine plant particles and all the micro-organisms except the very smallest. Thiamine estimations were done on samples of the sludge and of the supernatant fluid. Some of the remainder of the supernatant fluid was centrifuged at $8000 \mathrm{~g}$ for $30 \mathrm{~min}$ at $-\mathrm{I}^{\circ}$ to remove all bacterial cells, and the thiamine concentration in the supernatant fluid, hereafter called the 'cell-free' supernatant fluid, was determined. The deposit from this final treatment was too small to allow its thiamine content to be estimated.

Four large samples of rumen contents were treated in this way, but only two fractions were examined in subsequent samples, namely, the deposit obtained after centrifuging at $2500 \mathrm{~g}$ for $30 \mathrm{~min}$ and the cell-free supernatant fluid derived from high-speed 
centrifugation. This procedure allowed an approximate partition to be made between the quantity of thiamine in solution and the quantity in the deposit. The deposit consisted of plant debris, micro-organisms and trapped rumen fluid.

\section{Thiochrome determination}

The procedure recommended by the Analytical Methods Committee, Society of Public Analysts and other Analytical Chemists (1951) was closely followed, with only minor modifications, the most important of which was the use of a small quantity of glacial acetic acid to acidify the material for preliminary digestion and to determine the $\mathrm{pH}$ by glass electrode instead of relying on indicators (Analytical Methods Committee, Society of Public Analysts and other Analytical Chemists, 195I). The enzyme solution consisted of $3 \mathrm{~g}$ papain (в.P.C.) and $3 \mathrm{~g}$ Takadiastase (Parke, Davis and Co., standardized by dilution with lactose) made up in $100 \mathrm{ml}$. of $2.4 \mathrm{M}$-sodium acetate buffered at $\mathrm{pH}_{4}$ by the addition of $2 \cdot 4 \mathrm{M}$-acetic acid. The solution was freshly prepared for every determination. A suitably sized sample proved to be $\mathrm{I} 0 \mathrm{~g}$ of food, rumen contents or of a fraction of the rumen contents. A recovery experiment with thiamine added to rumen contents was done with every determination; if the recovery of added thiamine was less than $80 \%$, the value for the unknown was rejected. No corrections based on recovery figures have been made to the results presented in this paper because the error introduced by such adjustments may be greater than if no adjustment is made (Ridyard, $195^{\circ}$ ). The results are expressed as $\mu \mathrm{g}$ thiamine per $\mathrm{g}$ of food or of contents, the latter referring to the sample as drawn from the rumen or the intestines, unless otherwise stated.

\section{Rat assays}

Litters of weanling rats, reduced to an even number of each sex, were placed on the thiamine-free diet previously used by Phillipson \& Reid (1954). They were divided into groups of six or eight rats, balanced for sex and litter. Supplementation began when all animals in the group were losing weight. Graded quantities of thiamine hydrochloride from a stock solution were added daily to the food of those groups that were to receive the standard preparations. Rumen contents prepared in various ways were added to the food of the experimental groups at different levels based on the dry-matter content. Fresh, dried and semi-dried rumen contents were used. Drying was always carried out after the material had been acidified to $\mathrm{pH} 4$ or below, to avoid destruction of thiamine. The rumen contents were from sheep maintained on hay either with supplement no. 6 or with supplement no. I.

\section{RESULTS}

\section{Thiamine content of the food}

Results of determinations by the thiochrome method of the thiamine content of the supplements fed at various times are given in Table $\mathrm{I}$. It can be seen that supplement no. 6 contained more thiamine than supplement no. $x$. The low figure for fresh 
fodder-beet is related to the dry-matter content of these roots, approximately $25 \%$. The highest values were obtained for groundnut meal.

The variations observed in pasture grass and hay are given in Table 2 . The thiamine content of the grass was higher during the wet summer of 1954 than during the dry season of 1955 . The content in 1954 fell from $8 \cdot 1$ to $5.6 \mu \mathrm{g} / \mathrm{g}$ dry matter from July to October. The concentrations in grass cubes were regular except for one high value. The considerable variation found in the various hays used is understandable in view of the variations in the grass, and was presumably related to the season and the time of cutting.

Table I. Thiamine content of the foodstuffs

$\begin{array}{lrcc} & \mu \mathrm{g} / \mathrm{g} \text { as fed } & \mu \mathrm{g} / \mathrm{g} \text { dry matter } \\ \text { Groundnut meal } & 9 \cdot 2 & 9 \cdot \mathrm{I} & 10 \cdot 3 \\ \text { Flaked-maize supplement } & 2 \cdot \mathrm{I} & - & 2 \cdot 5 \\ \text { Supplement no. 6 } & 5 \cdot 4 & 5 \cdot 7 & 6 \cdot 4 \\ \text { Supplement no. I } & 3 \cdot 4 & - & 4 \cdot 0 \\ \text { Fodder-beet } & 1 \cdot \mathrm{I} & 0 \cdot 8 & 4 \cdot 7\end{array}$

Table 2. Thiamine content of the grass and grass products

\begin{tabular}{|c|c|c|c|c|}
\hline \multirow[b]{3}{*}{ Product } & \multirow[b]{3}{*}{$\begin{array}{c}\text { No. of } \\
\text { samples }\end{array}$} & \multicolumn{3}{|c|}{ Thiamine } \\
\hline & & \multicolumn{2}{|c|}{$\mu \mathrm{g} / \mathrm{g}$ as fed } & \multirow{2}{*}{$\begin{array}{c}\mu \mathrm{g} / \mathrm{g} \\
\text { dry } \\
\text { matter }\end{array}$} \\
\hline & & Range & Mean value & \\
\hline Fresh grass (June to October) & 5 & $1 \cdot 0-2 \cdot 3$ & $\mathrm{I} \cdot 5$ & $5 \cdot 4$ \\
\hline Grass cubes & 5 & $3 \cdot 0-5 \cdot 1$ & $3 \cdot 8$ & $4 \cdot 3$ \\
\hline Hay & 9 & $I \cdot I-3 \cdot 2$ & $1 \cdot 9$ & $2 \cdot 4$ \\
\hline
\end{tabular}

Table 3. Estimated daily intake of thiamine in the food and its concentration in the whole ration

\begin{tabular}{|c|c|c|c|}
\hline \multirow[b]{2}{*}{ Ration } & \multicolumn{2}{|c|}{ Daily intake (mg) } & \multirow{2}{*}{$\begin{array}{c}\text { Mean concen- } \\
\text { tration } \\
\text { in the food } \\
\text { ( } \mu \mathrm{g} / \mathrm{g} \\
\text { dry matter) }\end{array}$} \\
\hline & Range & Mean & \\
\hline Hay & $I \cdot 5-4 \cdot 4$ & $2 \cdot 6$ & $2 * 4$ \\
\hline Hay with supplement no. 6 & $2 \cdot 2-4 \cdot 2$ & $2 \cdot 9$ & $3 \cdot 2$ \\
\hline Hay with supplement no. I & $I \cdot 5-2 \cdot 9$ & $2 \cdot 0$ & $2 \cdot 8$ \\
\hline Hay with flaked-maize supplement & $2 \cdot 0-2 \cdot 4$ & $2 \cdot 2$ & 2.5 \\
\hline Hay with fodder-beet & $3 \cdot 2-5 \cdot 2$ & $4 \cdot 1$ & 3.9 \\
\hline Hay with groundnut meal & $3 \cdot 8-5 \cdot 3$ & $4 \cdot 4$ & 4.0 \\
\hline Grass cubes & $4 \cdot 1-6 \cdot 9$ & $5 \cdot 2$ & $4 \cdot 3$ \\
\hline Grass* & $5 \cdot 4-12 \cdot 1$ & $8 \cdot 1$ & $5 \cdot 4$ \\
\hline
\end{tabular}

The probable daily intakes of thiamine by the sheep eating the various rations are given in Table 3 . The rations fell into two distinct groups: those providing mean intakes of $2-3 \mathrm{mg}$ thiamine daily and those providing mean intakes of $4-8 \mathrm{mg}$ daily.

The dry matter eaten by the sheep when grazing was assumed for the purpose of these calculations to be $1500 \mathrm{~g}$ daily and it was also assumed that all sheep ate their full quota of grass cubes, which did not always happen. No one knows the daily minimum requirements of ruminants for thiamine but there was no likelihood of 
a deficiency occurring on the rations containing 4-8 $\mathrm{mg}$ even if no synthesis occurred in the alimentary tract. Deficiency presumably could have occurred only if extensive destruction had taken place.

\section{Thiamine concentration in the rumen}

Many samples were withdrawn from the rumen and the thiamine concentrations were estimated by the thiochrome method: the mean values for individual sheep are given in Table 4. Since these samples were withdrawn by suction through a tube with an internal diameter of $9 \mathrm{~mm}$, they were not representative of the whole contents, for the large particles of food tended to clog the tube. This inaccuracy is not important,

\section{Table 4. Mean concentrations of thiamine in the rumen contents} $(\mu \mathrm{g} / \mathrm{g})$ of sheep fed on different rations

\begin{tabular}{|c|c|c|c|c|c|c|c|c|}
\hline $\begin{array}{c}\text { Sheep } \\
\text { no. }\end{array}$ & $\begin{array}{c}\text { Hay with } \\
\text { flaked-maize } \\
\text { supplement }\end{array}$ & Hay & $\begin{array}{c}\text { Hay with } \\
\text { supplement } \\
\text { no. I }\end{array}$ & $\begin{array}{c}\text { Hay with } \\
\text { supplement } \\
\text { no. } 6\end{array}$ & $\begin{array}{l}\text { Hay with } \\
\text { groundnut } \\
\text { supplement }\end{array}$ & $\begin{array}{c}\text { Hay with } \\
\text { fodder- } \\
\text { beet }\end{array}$ & Grass & $\begin{array}{l}\text { Grass } \\
\text { cubes }\end{array}$ \\
\hline 1044 & - & $0.52(9)$ & - & $0.55(8)$ & $x \cdot 02(6)$ & - & $I \cdot 38(4)$ & - \\
\hline 1048 & 一 & - & $\ldots$ & $0.44(6)$ & - & - & - & - \\
\hline 1050 & $\ldots$ & $0.55(9)$ & - & 0.5 I (8) & $0.95(6)$ & - & $I \cdot 49(4)$ & - \\
\hline 1058 & - & - & - & $0.49(6)$ & - & - & - & - \\
\hline 242 & 0.54 (10) & $0.53(5)$ & $0.53(1)$ & $\ldots$ & - & - & $I \cdot 3 I(I I)$ & $0.99(6)$ \\
\hline 243 & - & - & $0.92(1)$ & $0.54(8)$ & - & $0.68(6)$ & - & - \\
\hline 249 & $0.67(9)$ & - & $0.80(2)$ & - & - & - & - & - \\
\hline 257 & $0.73(10)$ & - & $0.61(2)$ & - & - & $\ldots$ & - & - \\
\hline 259 & $0.51(10)$ & $0.59(5)$ & $0.49(2)$ & - & 一 & - & $\mathrm{I} \cdot 4 \mathrm{I}(\mathrm{I} I)$ & $1.08(6)$ \\
\hline 264 & $0.55(10)$ & - & $0.58(2)$ & - & - & - & - & - \\
\hline 277 & - & - & $0.42(I)$ & $0.56(9)$ & 一 & $0.69(6)$ & - & - \\
\hline $29 I$ & - & - & - & $0.55(9)$ & - & $0.70(6)$ & - & - \\
\hline 299 & $0.5^{8}(10)$ & $0.56(6)$ & $0.63(1)$ & - & - & - & $I \cdot 33$ (IO) & $I \cdot 26(5)$ \\
\hline 300 & 0.53 (I I) & $0.46(6)$ & $0.52(2)$ & - & - & - & $\mathrm{I} \cdot 22$ (I I) & $I \cdot 15(6)$ \\
\hline 309 & 0.64 (10) & - & $0.59(2)$ & - & - & - & - & - \\
\hline 310 & - & - & $0.79(x)$ & $0.53(8)$ & - & $0.58(6)$ & - & - \\
\hline
\end{tabular}

Figures in parentheses denote the number of samples from which the mean values were derived.

as is apparent later, unless it is necessary to compare critically the concentrations of thiamine in the food and in the total rumen contents. The figures in Table 4 cannot be compared directly with those given by others for the rumen contents of cattle, for those have always been expressed as $\mu \mathrm{g} / \mathrm{g}$ of the dry matter of the whole contents. The percentage dry matter of the samples used here varied with the ration, but usually it was between 5 and $10 \%$, which is lower than is obtained for whole rumen contents. The mean values for all estimations are listed in Table 5 .

The feeding of hay or of hay with supplement no. 6 produced the lowest mean values; hay with supplement no. I, with the flaked-maize supplement or with fodderbeet produced intermediary values of $0.6-0.7 \mu \mathrm{g} / \mathrm{g}$, and hay with groundnut mealthe supplement with the greatest thiamine content-grass cubes and grass produced the highest values in the rumen. At first sight the concentration of thiamine in the rumen appears to have been directly related to the thiamine concentration of the food but there were exceptions. There is no obvious reason why hay with supplement 
no. I or with the flaked-maize supplement should have been better than hay alone or hay with supplement no. 6. Similarly, hay with fodder-beet might be expected to have produced concentrations equal to those of hay with groundnut meal, since the concentrations of thiamine in the two rations were nearly identical, but it did not. The concentrations of thiamine in the rumen of grazing sheep did not follow closely the concentrations in the pasture, so that, although there was an obvious increase when the diet changed (Fig. 2), other factors must have been involved in determining the concentrations in the rumen contents.

\section{Table 5. Variation in the thiamine content of rumen samples taken from sheep on the different rations}

\begin{tabular}{|c|c|c|c|c|}
\hline \multirow[b]{2}{*}{ Ration } & \multirow[b]{2}{*}{$\begin{array}{l}\text { No. of } \\
\text { samples }\end{array}$} & \multirow[b]{2}{*}{$\begin{array}{l}\text { No. of } \\
\text { sheep }\end{array}$} & \multicolumn{2}{|c|}{$\begin{array}{l}\text { Thiamine content of rumen } \\
\text { samples }(\mu \mathrm{g} / \mathrm{g})\end{array}$} \\
\hline & & & Range & Mean \\
\hline Hay & $3^{6}$ & 6 & $0.23-0.70$ & 0.53 \\
\hline Hay with supplement no. 6 & 50 & 8 & $0.36-0.68$ & 0.53 \\
\hline Hay with supplement no. I & 17 & I I & $0.42-0.92$ & 0.60 \\
\hline Hay with flaked-maize supplement & 70 & 8 & $0.23-1 \cdot 00$ & 0.62 \\
\hline Hay with fodder-beet & 24 & 4 & $0.50-0.87$ & 0.66 \\
\hline Hay with groundnut supplement & 12 & 2 & $0.80-1 \cdot 15$ & 0.98 \\
\hline Grass cubes & I7 & 4 & $0.72-1 \cdot 55$ & $I \cdot I 2$ \\
\hline Fresh grass & 40 & 6 & $0.67-1 \cdot 89$ & $1 \cdot 32$ \\
\hline
\end{tabular}

\section{Partition of thiamine in the rumen contents}

An assessment of the quantity of thiamine in three phases of the rumen contents was made on four large samples by the method previously described. The results are given in Table 6.

Table 6. Approximate partition of thiamine between the three phases of the rumen samples derived from $100 \mathrm{~g}$ of the original sample

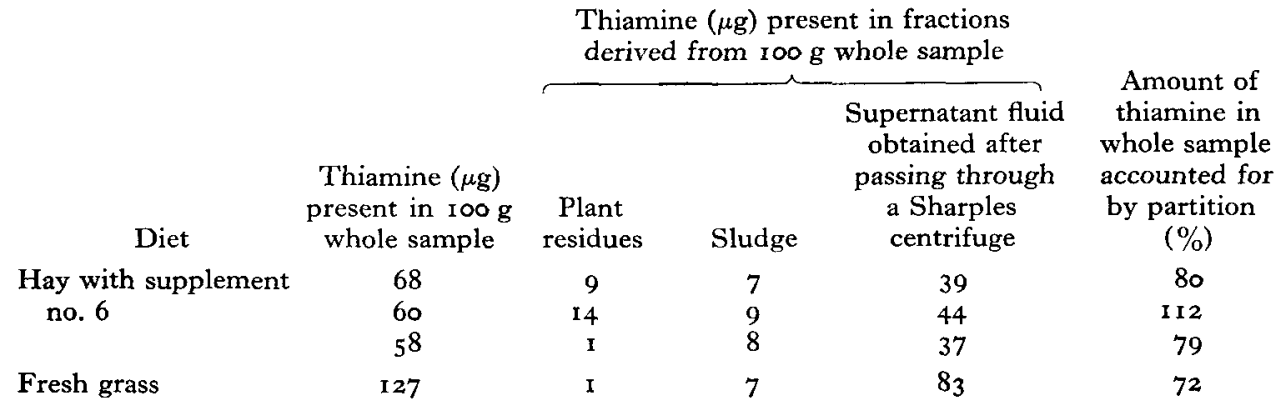

The percentage of the total thiamine content accounted for by these procedures indicates the approximate nature of the partition. Even so, it is clear that most of the thiamine was in the supernatant fluid obtained after passing the muslin filtrate through a Sharples centrifuge. Since only very small organisms were left in the Sharples centrifugate, it is almost certain that most of the thiamine was in solution. The results given in Table 7 show that this was so. 
The determination of thiamine in the cell-free supernatant fluid was also done on two samples not previously incubated with Takadiastase, so that esterified thiamine was not freed. Thiamine pyrophosphate is not soluble in isobutanol and, unless a preliminary hydrolysis has been carried out, it cannot be extracted. As can be seen from Table 7 , very small quantities were extracted by the $i$ sobutanol, but as pointed out by Harris \& Wang (194I) it might be due to esterified thiamine dissolving in the small amount of water contained in the wet isobutanol employed to extract free thiamine.

\section{Table 7. Concentrations of thiamine $(\mu \mathrm{g} / \mathrm{g})$ in the liquid} phases of the rumen contents

$\begin{array}{cccccc}\text { Diet } & \begin{array}{c}\text { Whole } \\ \text { contents }\end{array} & \begin{array}{c}\text { After filtering } \\ \text { through gauze }\end{array} & \begin{array}{c}\text { After passing } \\ \text { through a Sharples } \\ \text { centrifuge }\end{array} & \begin{array}{c}\text { Cell-free } \\ \text { supernatant } \\ \text { fluid }\end{array} & \begin{array}{c}\text { Non-esterified } \\ \text { thiamine in } \\ \text { cell-free } \\ \text { supernatant fluid }\end{array} \\ \text { Hay with } & 0.68 & 0.56 & 0.56 & 0.52 & - \\ \text { supplement no. } 6 & 0.60 & 0.54 & 0.55 & 0.58 & 0.06 \\ \text { Fresh grass } & 0.58 & 0.54 & 0.46 & 0.45 & 0.03 \\ \text { Fi.27 } & \mathbf{1 . 2 7} & \mathbf{1 . 3 2} & 1.30 & \mathbf{1 . 2 8} & -\end{array}$

Table 8. Mean values $(\mu \mathrm{g} / \mathrm{g})$ for the concentrations of thiamine in the samples of rumen contents as taken from the sheep and in solution in those samples

\begin{tabular}{lccc}
\multicolumn{1}{c}{ Diet } & $\begin{array}{c}\text { No. of } \\
\text { samples }\end{array}$ & $\begin{array}{c}\text { Sample as } \\
\text { taken from } \\
\text { the sheep }\end{array}$ & In solution \\
Hay & 3 & 0.55 & 0.52 \\
Hay with supplement no. 6 & 3 & 0.62 & 0.52 \\
Hay with fodder-beet & 4 & 0.69 & 0.71 \\
Hay with flaked-maize supplement & I & 0.80 & 0.88 \\
Hay with groundnut supplement & I & 0.95 & $1 \cdot 06$ \\
Grass cubes & 2 & $1 \cdot 14$ & $1 \cdot 22$ \\
Fresh grass & 4 & $\mathrm{I} \cdot 30$ & $1 \cdot 39$
\end{tabular}

Table 9. Concentrations of thiamine ( $\mu \mathrm{g} / \mathrm{g}$ dry matter) in the solid phases of the rumen contents compared with the concentrations in the samples as taken from the sheep

$\begin{array}{lccc}\text { Diet } & \begin{array}{c}\text { Sample as } \\ \text { taken from } \\ \text { the sheep }\end{array} & \begin{array}{c}\text { Plant } \\ \text { residues }\end{array} & \text { Sludge } \\ \text { Hay with supplement no. } 6 & 6 \cdot 0 & \mathbf{I} 56 & \mathbf{I} \cdot 28 \\ & 9 \cdot 2 & 0.40 & 4 \cdot 52 \\ & 10 \cdot 3 & 0 \cdot 35 & 4 \cdot 0 \mathrm{x} \\ \text { Fresh grass } & 20 \cdot 3 & 0.30 & 3 \cdot 44\end{array}$

A comparison of the concentrations of thiamine in the rumen samples as taken from the sheep fed on the different rations and in solution in the cell-free rumen liquor is given in Table 8 . With the exception of the first two values the mean concentrations were slightly greater in solution than in the whole contents.

The concentration of thiamine in the sludge (Table 9) was considerably greater than in the washed plant residues, with one exception. Even so the values found were much less than those for the whole samples when these values were expressed per $g$ dry matter. The values for sludge may be taken as the nearest representation of the 
concentration of thiamine within rumen micro-organisms when considered in mass; the small amount of rumen liquid trapped in the sludge would mean that the value was greater than it should have been, since the liquid contained a higher concentration of thiamine than the sludge. The quantity and concentration of intracellular thiamine therefore was small compared with that of the extracellular thiamine.

\section{Change from one ration to another}

A close watch was kept on some of the sheep when the ration was changed. Samples were withdrawn at $6,24,48,72$ and $96 \mathrm{~h}$ after the change and thereafter at longer intervals. In calculating the mean values given in Tables 4 and 5 no value was included for samples drawn before $96 \mathrm{~h}$ had elapsed after the change of ration.

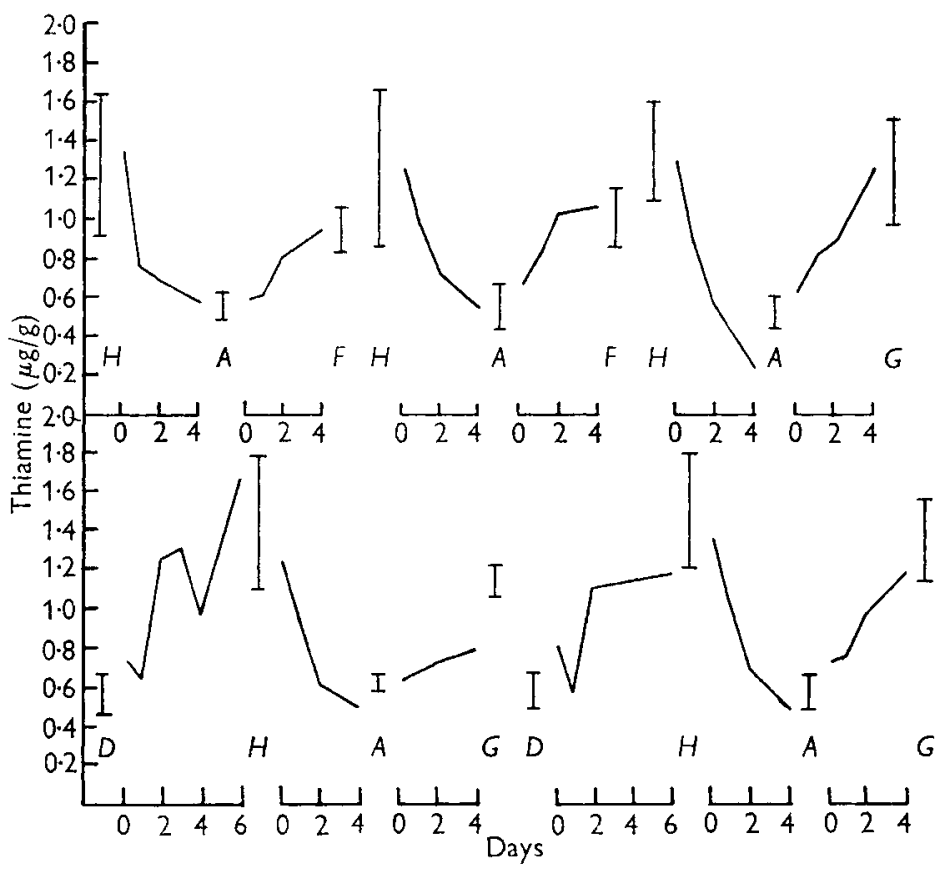

Fig. I. The range of values found for thiamine $(\mu \mathrm{g} / \mathrm{g})$ in rumen contents of sheep fed on five rations is given by the vertical lines marked according to the key given on p. 28. The speed with which the concentrations changed from one range to another is shown by the values plotted in between the vertical lines. The first plots are made from samples taken $6 \mathrm{~h}$ after the ration was changed. $A$, chopped hay; $D$, chopped hay and flaked-maize mixture; $F$, chopped hay and groundnut supplement; $G$, grass cubes; $H$, fresh grass.

Usually the concentration in the rumen had reached the new level at the $4^{\text {th }}$ day after the change. This was so with fifteen of the twenty changes observed; the delay, when it occurred, was probably due to the time taken by the sheep to become accustomed to the new food. When the ration was changed to hay with flaked maize, values as low as $0.2 \mu \mathrm{g} / \mathrm{g}$ were occasionally obtained. Typical effects observed are illustrated in Fig. I. 


\section{Thiamine concentration in the intestines}

Three experiments were done in which samples were taken from slaughtered sheep so that the concentrations of thiamine in the different parts of the alimentary tract could be compared. The method was not very satisfactory since, in the small intestine in particular, food was not always in the part of the intestine from which samples were required. The use of intestinal cannulas gets over this difficulty, as material flows from the cannulas only when food is being propelled along the part of the intestine involved.

Table 10. Concentrations of thiamine $(\mu \mathrm{g} / \mathrm{g})$ in individual samples obtained from different parts of the alimentary tract of freshly killed sheep and of cannulated normally feeding sheep

\begin{tabular}{|c|c|c|c|c|c|c|c|c|}
\hline Ration & Rumen & Abomasum & Duodenum & Jejunum & Ileum & Caecum & Colon & Faeces \\
\hline \multicolumn{9}{|c|}{ Killed sheep } \\
\hline Hay with supple- & 0.39 & 0.02 & o.01 & 0.34 & 0.15 & O. I 5 & 0.55 & -- \\
\hline ment no. 6 & 0.64 & 0.16 & 0.30 & 0.07 & 0.01 & 0.08 & 0.19 & - \\
\hline & 0.34 & 0.41 & 0.18 & 0.07 & 0 & 0.18 & 0.19 & - \\
\hline \multicolumn{9}{|c|}{ Cannulated sheep } \\
\hline Grass cubes (8) & 0.92 & - & 0.46 & - & 0.52 & 0.62 & - & $\mathrm{I} \cdot 4 \mathrm{I}$ \\
\hline Hay (6) & $0 \cdot 46$ & 一 & $0: 31$ & - & 0.10 & 0.25 & - & 0.43 \\
\hline $\begin{array}{l}\text { Hay with supple- } \\
\text { ment no. } 6(3)\end{array}$ & 0.63 & - & 0.37 & - & $0 \cdot 18$ & 0.33 & - & 0.69 \\
\hline
\end{tabular}

Figures in parentheses denote the total number of samples from which the mean values were derived.

A comparison of the values obtained by the slaughter methods and by collection from cannulas is given in Table ro. Two sheep were used for the cannulation experiment, and the mean of all values for both animals are given in Table ro. Variations were not large, so that the mean figures are themselves representative. The values from the cannulated sheep fed on hay with supplement no. 6 agree reasonably well with those for slaughtered sheep. The sheep fed on grass cubes had greater concentrations of thiamine throughout the gut than those fed on other rations. The concentrations in duodenal contents were appreciable, but dropped by a half or more by the time the food reached the ileum except when grass cubes had been fed. When these values were expressed as concentrations of the dry matter and plotted in Fig. 2, it was found that an increase in concentration occurred in the caecum only when hay was fed alone. On the other hand, the content of the fresh material tended to rise in the caecum of cannulated sheep, as shown in Table 1o. The quantities of thiamine excreted in the faeces were appreciable but the concentrations were less than those in the food when compared on a dry-matter basis. The variation in concentration throughout the day in sheep fed on hay with a groundnut supplement or grazing was not great either in the rumen or in the duodenum and caecum, as is seen from the mean values given in Table Ir. The increase from 9.00 a.m. to 3.00 p.m., however, was regular except in the caecum. Fractionation of the intestinal contents into the deposit obtained by centrifugation at $2500 \mathrm{~g}$ for $30 \mathrm{~min}$ and the cell-free supernatant fluid showed that in the duodenum, as in the rumen, most of the thiamine was in the supernatant fluid. The position was reversed in the caecum, as shown in Table 12 . This finding was due 


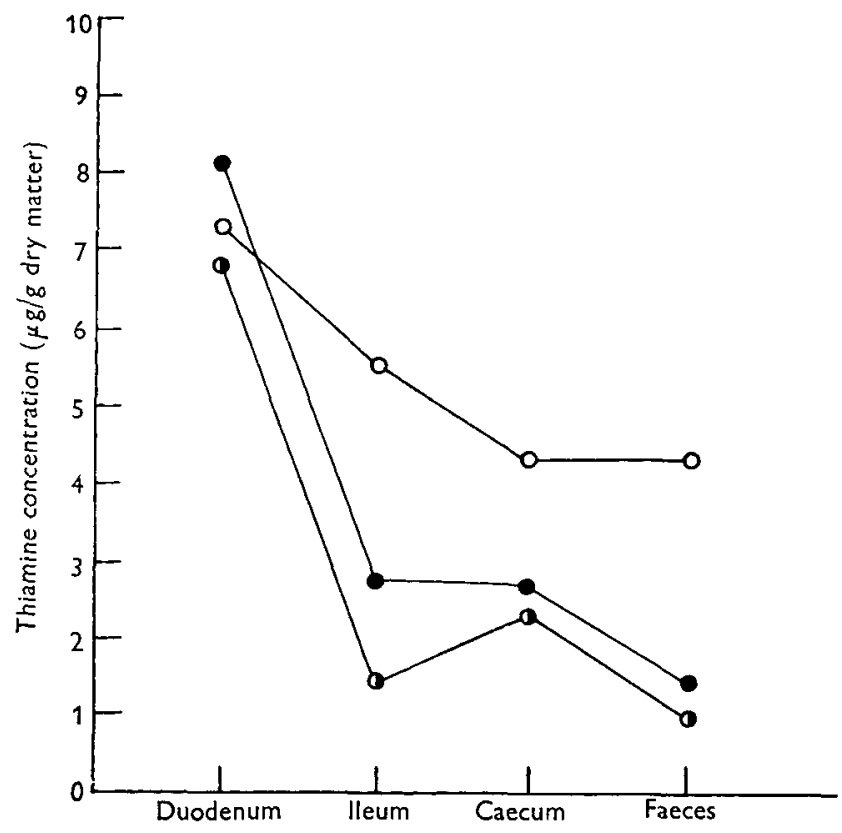

Fig. 2. Mean concentration of thiamine in the dry matter of digesta taken from the duodenum, ileum and caecum and in the faeces. $\circ-0$, sheep fed on grass cubes; $\bullet \bullet$, sheep fed on hay with supplement no. 6; $1-0$, sheep fed on hay.

Table I1. Variation throughout the day in the thiamine content $(\mu \mathrm{g} / \mathrm{g})$ of the rumen, duodenal and caecal contents, each value being the mean of three determinations

$\begin{array}{ccccc}\text { Diet } & \text { Time } & \text { Rumen } & \text { Duodenum } & \text { Caecum } \\ \text { Hay with groundnut supplement } & 9.00 \mathrm{a.m} . & 0.94 & 0.54 & 0.54 \\ & 12.00 \text { noon } & 1.01 & 0.59 & 0.59 \\ & 3.00 \mathrm{p} . \mathrm{m} . & 1.09 & 0.67 & 0.56 \\ \text { Fresh grass } & 6.00 \mathrm{p} . \mathrm{m} . & 0.91 & 0.58 & 0.61 \\ & 9.00 \mathrm{a} . \mathrm{m} . & 0.84 & 0.39 & 0.57 \\ & 3.00 \mathrm{p.m} . & 0.94 & 0.49 & 0.56\end{array}$

Table 12. Concentration of thiamine in the solid and liquid phases of the digesta, and total thiamine present in each fraction

\begin{tabular}{|c|c|c|c|c|c|c|}
\hline \multirow[b]{2}{*}{ Organ } & \multirow[b]{2}{*}{ Sheep no. } & \multicolumn{3}{|c|}{ Concentration $(\mu \mathrm{g} / \mathrm{g})$ in } & \multicolumn{2}{|c|}{$\begin{array}{l}\text { Total quantity }(\mu \mathrm{g}) \\
\text { derived from } 100 \mathrm{~g} \\
\text { samples }\end{array}$} \\
\hline & & $\begin{array}{l}\text { Whole } \\
\text { sample }\end{array}$ & Deposit & $\begin{array}{l}\text { Cell-free } \\
\text { liquor }\end{array}$ & Deposit & $\begin{array}{l}\text { Cell-free } \\
\text { liquor }\end{array}$ \\
\hline Rumen & $\begin{array}{l}\text { I044 } \\
\text { 1050 }\end{array}$ & $\begin{array}{l}0.78 \\
1 \cdot 38\end{array}$ & $\begin{array}{l}0.34 \\
0.75\end{array}$ & $\begin{array}{l}0.69 \\
I \cdot 11\end{array}$ & $\begin{array}{r}8 \\
31\end{array}$ & $\begin{array}{l}54 \\
66\end{array}$ \\
\hline Duodenum & $\begin{array}{l}1044 \\
1050\end{array}$ & $\begin{array}{l}0.53 \\
0.52\end{array}$ & $\begin{array}{l}0.33 \\
0.33\end{array}$ & $\begin{array}{l}0.51 \\
0.42\end{array}$ & $\begin{array}{l}7 \\
9\end{array}$ & $\begin{array}{l}40 \\
31\end{array}$ \\
\hline Caecum & $\begin{array}{l}1044 \\
1050\end{array}$ & $\begin{array}{l}0.65 \\
0.59\end{array}$ & $\begin{array}{l}0.56 \\
0.34\end{array}$ & $\begin{array}{l}0.31 \\
0.64\end{array}$ & $\begin{array}{l}38 \\
23\end{array}$ & $\begin{array}{l}10 \\
21\end{array}$ \\
\hline
\end{tabular}


to the fact that a much larger deposit was obtained from the caecal than from the duodenal contents. Presumably the thiamine was mostly within bacterial cells in caecal contents, which may be an indication of synthesis. The two values obtained for caecal cell-free liquor showed a wide variation in relation to the initial concentration of the sample, but it may be noted that some of the thiamine was in solution in the caecum and consequently was in a condition in which it could be absorbed if the caecal epithelium is permeable to it.

\section{Rat assays of the thiamine present in the rumen contents}

Three assays with rats were made on rumen contents withdrawn from sheep fed on hay and supplement no. 6. These assays did not agree with the apparent thiamine concentration of the contents determined by the thiochrome method, but subsequent test with supplement no. 6 showed that rats have a distaste for linseed meal, which is probably the explanation for the failure of the first three assays. A further assay was made with the rumen contents withdrawn from sheep fed on hay with supplement no. I and the results obtained were of the order expected.

Three groups of rats were depleted; the first and second groups were given $5 \mu \mathrm{g}$ thiamine daily in their food, and the second group received, in addition, rumen contents in which the thiamine had been destroyed by heating in the presence of sulphite. The third group received fresh rumen contents, untreated in any way, in quantities equal to those given to group 2. The rumen contents were added at a rate calculated to replace $20 \%$ of the dry matter of the ration. According to the thiochrome determinations on the rumen contents used, the rats in group 3 received IO-I $2 \mu \mathrm{g}$ thiamine daily in $\mathrm{ro} g$ of food.

The weight gains made by rats of groups 1 and 2 were regular and the average increases during 18 days were 46 and $52 \mathrm{~g}$ respectively, showing that the relatively high level of rumen contents in the ration did not interfere with the growth of the rats. The rats of group 3 gained on an average $9 \mathrm{I} g$ in 18 days which was greater than the gain made by the control rats used in the earlier assays that received Io $\mu \mathrm{g}$ thiamine daily.

\section{DISCUSSION}

Most investigations on B-vitamins in rumen contents have been done with the object of establishing whether synthesis does or does not occur in the rumen and comparisons of the factor studied have been made on the dry matter of the food and the rumen contents. Lardinois, Mills, Elvehjem \& Hart (1944), Kesler \& Knodt (I952) and Agrawala, Huffman, Luecke \& Duncan (1953) all comment on the inconclusive nature of this method and hesitate to come to a firm conclusion on the question when foodstuffs containing substantial quantities of B-vitamins are fed, because concentration or dilution in a system such as the rumen may be due to a variety of causes. Nevertheless, it is generally accepted that the synthesis of B-vitamins occurs when semisynthetic rations containing little if any B-vitamins have been fed, for substantial concentrations have been found in the rumen contents. It appears that synthesis occurs when there is a vitamin deficiency in the food, but the evidence for synthesis 
when foodstuffs containing adequate quantities of B-vitamins are fed is still inconclusive (Kon \& Porter, 1954). For thiamine the most convincing evidence is that obtained by balance experiments. The original work of Bechdel \& Honeywell (1927) and of Bechdel, Honeywell, Dutcher \& Knutsen (1928) showed conclusively that vitamin $B_{1}$ was synthesized somewhere in the cow and probably in the rumen, and, since thiamine deficiency can be induced in the young sucking calf (Johnson, Hamilton, Nevens \& Boley, 1948), there seems little doubt that it is the alimentary flora and not the animal tissues that effect the synthesis. Recently Teeri, Leavitt, Josselyn, Colovos \& Keener (1950) found that cattle excreted daily in faeces and urine about twice the quantity of thiamine eaten daily in the food. The inclusion of sulphathalidine in the ration reduced the total excreted to a figure only slightly greater than the quantity eaten, and the greatest reduction occurred in the faecal thiamine.

The experiments reported here were not intended to add to or detract from the evidence in favour of synthesis, and no additional information on the question has come to light. It is clear that under any normal system of feeding, irrespective of whether synthesis does or does not occur, the ruminant does not run much risk of suffering from lack of thiamine in its food except when poor hays are fed alone. Kon \& Porter (1953), after a number of comparisons between the food and rumen contents of cattle, commented that the concentrations in the rumen bore a marked relation to the concentration in the food. A close examination of the results reported here supports this opinion that there is a general relationship, but a study of individual results by plotting values obtained from sheep close to the time when the food was sampled, so that particular and not average comparisons can be made, shows that the relationship is not a particularly close one.

The grazing sheep seems interesting in this respect. The pasture grass in 1954 had its highest thiamine content at the beginning of July, and the concentration fell as the summer progressed. The concentrations found in the rumen contents for two sheep that went to pasture in May rose until the end of June, but fell in July and remained steady until September. Two other sheep went to the same pasture in July, and the concentration of thiamine in their rumen contents rose to high values in August and thereafter remained steady. The immediate result of sheep going to pasture was a rapid rise in the thiamine present in the rumen, which was undoubtedly due to the high thiamine content of the grass. The later changes appear to have depended upon other factors than the thiamine content of the food. It is probable that discrepancies between the thiamine concentrations of the food and those of the rumen contents are due to differences in the relative numbers of the rumen micro-organisms that produce or use thiamine.

Throughout the whole gut of the sheep most of the thiamine is in solution; in the rumen at any rate it is present as the pyrophosphate. Presumably thiamine in solution can be absorbed in any part of the stomach or gut. Kon \& Porter (1955) have proof of absorption from the rumen, but no one has examined the ability of the intestines to absorb this vitamin. It has been suggested that the caecal and colonic mucosas are not readily permeable to B-vitamins; there is no evidence to show whether this is so or not, but it is perhaps reasonable to assume that anything in solution in the 
alimentary tract can be absorbed unless there is positive evidence to the contrary. Our attempts to determine thiamine in blood by the thiochrome method were not satisfactory, since recoveries of added thiamine were only $50-60 \%$. For this reason we have not attempted to study absorption of thiamine by this method. The concentrations of thiamine in the dry matter of the intestinal contents illustrated in Fig. 2 showed an increase in the caecum only with sheep fed on hay; this may have been an indication of synthesis in the caecum with this particular ration. Otherwise the results are in keeping with those of Kesler \& Knodt (I95I), who found no increase in the thiamine concentrations of the caecal contents of $\mathrm{i} 6$-week-old calves when compared with those of the small intestine; large increases of thiamine in the caecum were found only with young calves (Kesler \& Knodt, 1952).

Food residues form a considerable part of the deposit obtained from caecal contents, and since the washed food residues of the rumen contained little thiamine (Table 6) those of the caecum probably contained even less. For this reason the thiamine present in the caecal deposit is likely to have been mostly within bacterial cells. This and the fact that the caecal deposit contained the greater part of the thiamine of the whole caecal sample may have been an indication of a dense bacterial population that is known to be different in many ways from the population found in the rumen, and may have been also an indication of thiamine synthesis in the caecum.

Kon \& Porter (1947-8) wisely emphasized the importance of comparing chemical and biological tests for B-vitamins in the rumen. The rat assay for thiamine in the rumen has been used previously by Hunt, Burroughs, Bethke, Schalk \& Gerlaugh (I94I, I943) and, although many of the results were positive, in certain of the assays there was little indication of the presence of thiamine. The chick assay was used also by McElroy \& Goss (I94I) and by Wegner, Booth, Elvehjem \& Hart (I940, 194I) without apparently any anomalous results occurring, although McElroy \& Goss (r94I) reported on a cow that according to this test appeared to have no thiamine in its rumen contents.

Previous work (Phillipson \& Reid, 1954) showed that depleted rats readily ate the rumen contents of cattle that had been fed on bracken or hay, and it was surprising to find in the first three assays in the present tests that depleted rats did not respond to the rumen contents of sheep fed with a more nutritious ration, for the food intake, although somewhat irregular, was judged to be enough to allow responses to occur. However, a subsequent test showed that normal rats would not eat linseed meal and the first three assays were therefore rejected. The final assay on rumen contents derived from sheep on a different ration was entirely satisfactory, and the results were in accord with the thiochrome determination of the thiamine supplied in the rumen contents.

\section{SUMMARY}

I. The thiochrome method has been used to study the concentration of thiamine in the rumen contents of sheep fed on one or the other of eight different rations. A general relationship was found between the thiamine content of the food and the thiamine concentration in the rumen contents. 
A. T. PHILLIPSON AND R. S. REID

Plate I

THIAMINE IN ALIMENTARY TRACT OF SHEEP
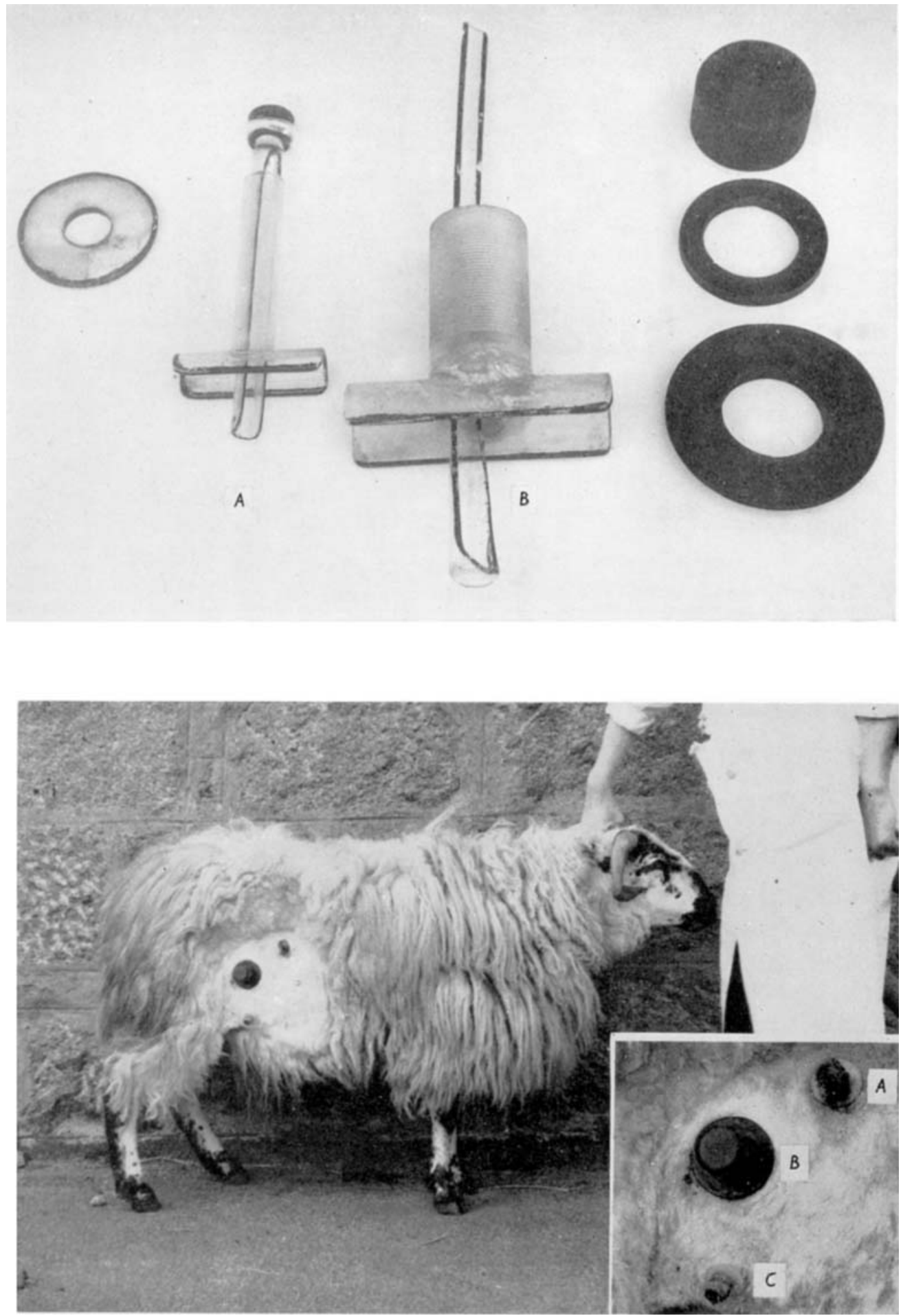

British Fournal of Nutrition, Vol. I I, No. I 
2. Very little thiamine was present in the coarse food residues in the rumen; appreciable concentrations were present in the fraction consisting of small food particles and micro-organisms, but most of the thiamine was extracellular and in solution. Preliminary hydrolysis was needed to render the thiamine present in rumen contents soluble in isobutanol.

3. The concentration of thiamine in the dry matter of the intestine decreased from the duodenum to the ileum. The concentration in the dry matter of the caecum was similar to that in the dry matter of the ileum except in hay-fed sheep.

4. Thiamine in the small intestine and caecum was shown to be in solution, but the proportion present in the solid deposit in the caecal contents was greater than in the solid deposit in other parts of the gut.

5. Biological assay of thiamine in rumen contents on depleted rats gave in one assay reasonable agreement with the thiochrome determination of the thiamine present. The rumen contents of sheep fed on one ration containing linseed meal did not give satisfactory results when tested in this way; this appeared to be due to the rat's distaste for linseed meal.

We wish to thank Dr R. J. Pennington for much advice on the chemical determination of thiamine and Clifton C. Stroud for assistance throughout the course of this work.

\section{REFERENCES}

Agrawala, I. P., Huffman, C. F., Luecke, R. W. \& Duncan, C. W. (I953). F. Nutr. 49,63I.

Analytical Methods Committee, Society of Public Analysts and other Analytical Chemists (1951). Analyst, 76, 127.

Bechdel, S. 1. \& Honeywell, H. E. (I927). F. agric. Res. 35, 283.

Bechdel, S. I., Honeywell, H. E., Dutcher, R. A. \& Knutsen, M. H. (I928). F. biol. Chem. 80, 23 I.

Carpenter, K. J., Phillipson, A. T. \& Thomson, W. (1950). Brit. vet. F. 106, 292.

Evans, E. T. R., Evans, W. C. \& Roberts, H. E. (1951). Brit. vet. F. 107, 364.

Harris, L. J. \& Wang, Y. L. (194I). Biochem. F. 35, 1050.

Hunt, C. H., Burroughs, E. W., Bethke, R. M., Schalk, A. F. \& Gerlaugh, P. (194r). F. Nutr. 2 I, 85. Hunt, C. H., Burroughs, E. W., Bethke, R. M., Schalk, A. F. \& Gerlaugh, P. (1943). $\mathscr{~ . ~ N u t r . ~} 25,207$. Johnson, B. C., Hamilton, T. S., Nevens, W. B. \& Boley, L. E. (1948). F. Nutr. 35, 137.

Kesler, E. M. \& Knodt, C. B. (r95 I). F. Anim. Sci. ro, 7 I4.

Kesler, E. M. \& Knodt, C. B. (1952). Proc. Soc. exp. Biol., N.Y., 79, 85.

Kon, S. K. \& Porter, J. W. G. (1947-8). Nutr. Abstr. Rev. 17, 3 I.

Kon, S. K. \& Porter, J. W. G. (1953). Proc. Nutr. Soc. 12, xii.

Kon, S. K. \& Porter, J. W. G. (1954). Vitam. \& Horm. 12, 53.

Kon, S. K. \& Porter, J. W. G. (I955). Personal communication.

Lardinois, C. C., Mills, R. C., Elvehjem, C. A. \& Hart, E. B. (1944). F. Dairy Sci. 27, 579.

McElroy, L. W. \& Goss, H. (1941). F. Nutr. 21, 163.

Naftalin, J. \& Cushnie, G. (I954). F. comp. Path. 64, 54.

Phillipson, A. T. \& Mitchell, R. L. (1952). Brit. F. Nutr. 6, 176.

Phillipson, A. T. \& Reid, R. S. (r954). \%. comp. Path. 64, 243.

Ridyard, H. N. (1950). Analyst, 75, 634.

Teeri, A. E., Leavitt, M., Josselyn, D., Colovos, N. F. \& Keener, H. A. (1950). 7. biol. Chem. r82, 509. Wegner, M. I., Booth, A. N., Elvehjem, C. A. \& Hart, E. B. (r940). Proc. Soc. exp. Biol., N. Y., 45, 769. Wegner, M. I., Booth, A. N., Elvehjem, C. A. \& Hart, E. B. (1941). Proc. Soc. exp. Biol., N. Y., 47, 90. Weswig, P. H., Freed, A. M. \& Haag, J. R. (1946). F. biol. Chem. 165, 737.

\section{EXPLANATION OF PLATE}

(Above) Duodenal cannula $(A)$ and caecal cannula $(B)$ with the collecting devices described in the text (p. 29) inserted through the shaft. The collar and cap of the caecal cannula are made of ebonite.

(Below) A sheep fitted with a duodenal $(A)$, ileal $(B)$ and caecal $(C)$ cannula. 